\title{
Profil Dan Minat Mahasiswa Studi Di UIN Malang Sebagai Dasar Penentuan Strategi
}

\author{
Slamet, Agus Sucipto, Eko Suprayitno
}

Dosen Fakuttas Ekonomi UIN Malang

\section{Abstract}

This research is to describe the student opinion on UIN Malang choice. In this qualitative and quantitative, to describe how student opinion about UIN Malang, who is student in UIN Malang, what department is student know and choice, and how to make marketing strategic to get the student. The finding showed that (I) the student in UIN malang is more than $75 \%$ from East Java, (2) The student is more than $70 \%$ from MA (Madrasah Aliyah) (3) more than 60\% the student have the aim to translator both Arabic and English. In marketing Strategic, (1) UIN malang must come the Market Leader, couse UIN Malang have reputable university in Muslim society especially in MA in East Java, (2) UIN Malang must have marketing division to make public market not only in East Java, but in Indonesian

\section{PENDAHULUAN}

\section{A. Latar Belakang}

Universitas Islam negeri Malang merupakan salah satu dari sekian banyak perguruan tinggi yang ada di Indonesia, sehingga dirasakan atau tidak sudah masuk 
dalam dunia persaingan pendidikan tinggi, khususnya yang ada di Kota Malang dan di Indonesia pada umumnya. Berkembang atau tidaknya perguruan tinggi ini salah satunya ditentukan oleh profil perguruan mahasiswa dan jumlah peminat mahasiswa masuk perguruan tinggi ini. Langkah paling awal adalah mengenali siapa yang menjadi segmen mahasiswa UIN Malang, dengan cara ini UIN Malang dapat mengembangkan profil-profil yang ada dan menilai daya tarik masing-masing segmen.

Langkah kedua, adalah menetapkan sasaran mahasiswa yang berisi kegiatan menilai, dan memilih satu atau lebih segmen. Product Positioning merupakan langkah ketiga dan mencakup kegiatan merumuskan penempat produk (jasa pendidikan) dalam persaingan dan menetapkan bauran pemasaran yang terperinci.

Mengapa UIN Malang harus merumuskan segmentasi, hal ini disebabkan adanya multiperan dan multikepribadian yang telah menyebabkan customer mobility -pergerakan dari satu peran, perilaku, dan kepribadian, ke peran, perilakı, dan kepribadian yang lain - menjadi semakin tinggi intensitasnya. Untuk dapat mengikuti dan memotret pergerakan pelanggan (mahasiswa) ini, diperlukan kreatifitas yang sangat tinggi. Diperlukan penglihatan yang lebih dinamis dan holistic terhadap pola piker, perilaku, dan preferensi mahasiswa, sehingga semua sisi akan terkena radar penglihatan.

Berangkat dari latar belakang masalah di atas, peneliti tertarik untuk melakukan penelitian siapa segmentasi dan apa minat mahasiswa studi di Universitas Islam Negeri Malang. Oleh sebab itu, penelitian ini diberi judul "PROFIL DAN MINAT MAHASISWA STUDI DI UIN MALANG SEBAGAI DASAR PENENTUAN STRATEGI"

\section{B. Rumusan Masalah}

1. Siapakah segmentasi pengguna jasa pendidikan UIN Malang?

2. Apa saja yang menjadi minat mahasiswa studi di UIN Malang ?

3. Faktor-faktor keputusan apakah calon mahasiswa menggunakan jasa pendidikan di UIN Malang? 
4. Bagaimana strategi yang harus dikembangkan dalam rangka menjaring calon mahasiswa

\section{Tujuan Penelitian}

1. Mendiskripsikan profil (segmentasi) mahasiswa pengguna jasa pendidikan di UIN Malang.

2. Mendiskripsikan minat apa saja yang menjadi pendorong mahasiswa melakukan studi di UNN Malang.

3. Ingin mengetahui media yang digunakan dalam mengenali dan memahami tentang UIN Malang secara umum.

4. Merumuskan strategi-strategi yang mungkin disa dikembangkan dalam rangka menjaring mahasiswa dan pelayanan pendidikan kepada mahasiswa.

\section{LANDASAN TEORI}

\section{A. Manajemen Pendidikan Tinggi}

Kemenade dan Garre (2000) mengidentifikasi delapan kategori yang dibutuhkan dari lulusan perguruan tinggi, sehingga dapat memenuhi permintaan industri, antara lain : (1) berorientasi pelanggan; (2) memiliki pengetahuan praktis dan aplikasi alat; (3) mampu membuat keputusan berdasarkan fakta; (4) memiliki pemahaman bahwa bekerja adalah suatu proses; (5) berorientasi pada kelompok (teamwork); (6) memiliki komitmen untuk peningkatan terus menerus; (7) pembelajaran aktif ; $(8)$ memiliki perspektif system.

Oleh karena itu, untuk mencapai tujuan pendidikan tinggi yaitu kualitas lulusan dengan berbagai pengertian tersebut, manajemen Perguruan Tinggi seyogyanya memandang bahwa Proses Pendidikan Tinggi adalah suatu peningkatan terus menerus (continuous educational process improvement), yang dimulai dari sederet siklus sejak adanya ide-ide untuk menghasilakn lulusan perguruan tinggi yang berkualitas, pengembangan kurikulum, proses pembelajaran, dan ikut bertanggung jawab untuk memuaskan pengguna lulusan perguruan tinggi

Ulul Albab, Vol. 5 No. 2, 2004 
yang bersangkutan. Seterusnya, berdasarkan informasi sebagai umpan-balik (feedback) yang dikumpulkan dari pengguna lulusan dapat dikembangkan ide-ide kreatif untuk mendesain ulang kurikulum atau memperbaiki proses pendidikan tinggi yang ada saat ini.

Gambar 1

\section{Manajemen Pendidikan Tinggi Modern}

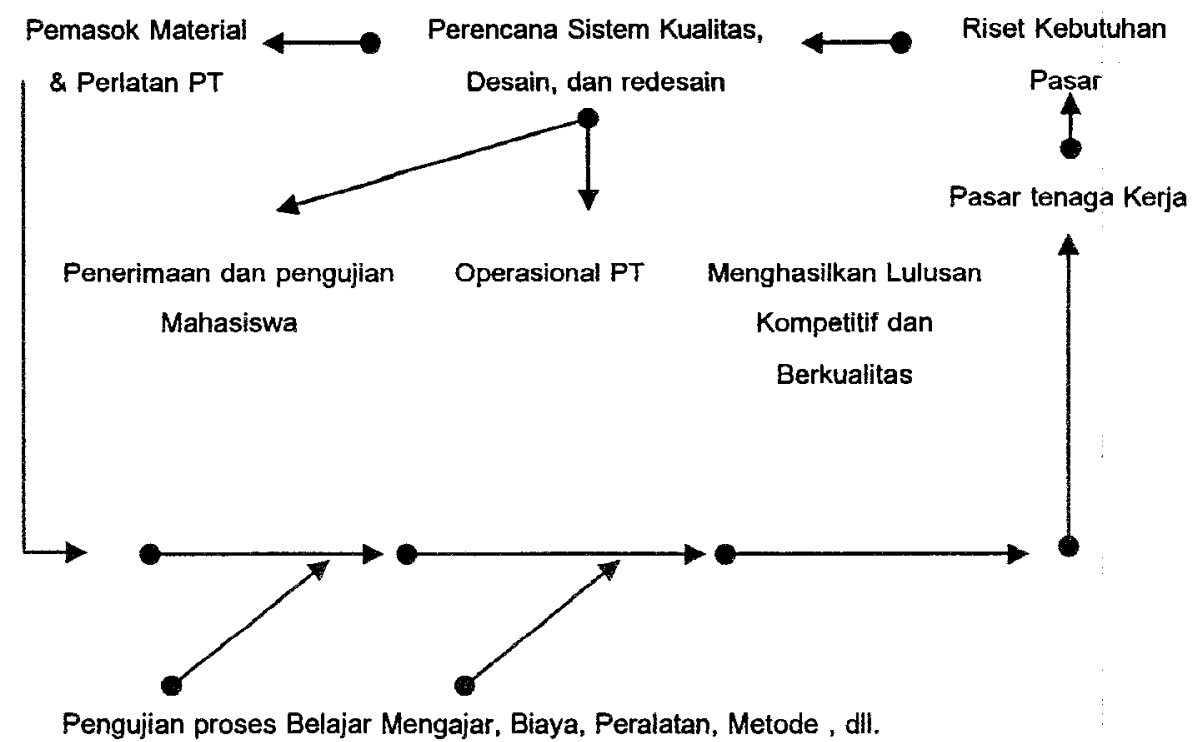

Ulul Albab, Vol. 5 No. 2, 2004 
Gambar 2:

\section{Roda Deming dalam Manajemen Pendidikan Tinggi}

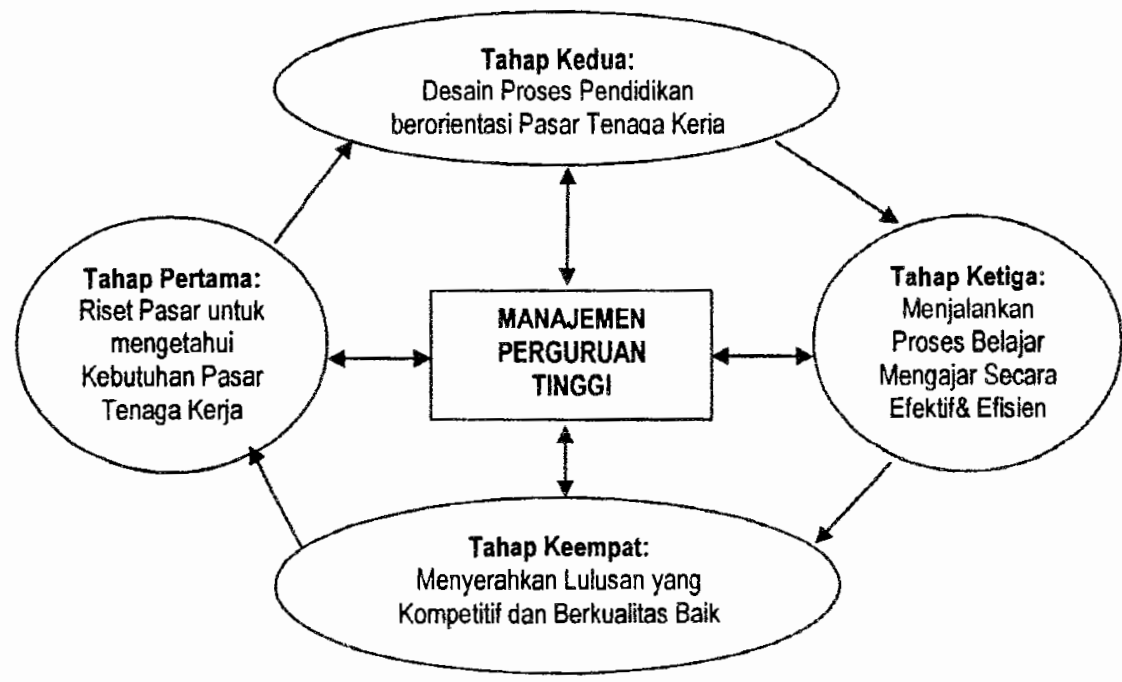

Sumber: Vincent Gasper (makalah)

\section{B. PROSEDUR MELAKUKAN SEGMENTASI}

Menurut Kotler (1993:376) ada beberapa tahapan dalam melakukan segmentasi, dimana prosedur ini harus dilakukan secara berkala, karena segmen selalu berubah, tahapan dimaksud, antara lain:

1. Melakukan survey atau market research. Pada tahap ini jumlah sampelnya harus banyak agar dapat terkumpul cukup data untuk membuat profil tiap segmen secara akurat.

2. Melakukan analisis. Alat analisis dalam mendukung hasil survey dapat digunakan dengan berbagai pendekatan, baik kauntatif maupun kualitatif.

3. Penyusunan profil. Setiap variable sebaiknya disusun profil-profil sehingga dapat ditemukan karakteristiknya dari segmen. 
Ada empat langkah dalam rangka melakukan segmentasi (Lupiyoadi, 2001:37), yaitu:

1. Pendefinisian pasar yang ingin dimasuki

2. Identifikasi dasar/basis alternative untuk segmentasi

3. Pengujian basis tersebut dan memilih dasar yang baik untuk segmentasi

4. Identifikasi segemen pasar individu, menunjukkan daya tariknya, dan seleksi akan segmen yang menjadi target secara spesifik

\section{MARKETING MIX PADA PERUSAHAAN JASA}

Marketing Mix adalah merupakan alat (tools) bagi seorang pemasar yang terdiri dari berbagai elemen suatu program pemasaran yang perlu dipertimbangkan agar implementasi strategi pemasaran dan positioning yang ditetapkan dapat berjalan sukses. Marketing mix untuk jasa berbeda dengan marketing mix pada produk dalam bentuk barang. Marketing mix jasa dikenal dengan 7 P yaitu Product, Price, Promotion, Place, People, Process, dan Customer Services.

Dalam mengukur tingkat kepuasan pelanggan, terdapat lima factor utama yang harus diperhatikan oleh perusahaan yaitu: Pertama, kualitas produk. Pengguna jasa akan merasa puas bila hasil evaluasi menunjukkan bahwa produk yang mereka gunakan berkualitas. Kedua, kualitas pelayanan. Terutama untuk industri jasa. Pelanggan akan merasa puas bila mereka mendapatkan pelayanan yang baik atau yang sesuai dengan yan diharapkan. Ketiga, adalah emosional. Pelanggan akan merasa bangga dan emndapatkan keyakinan bahwa orang lain akan kagum terhadap produk dengan merek tertentu yang cenderung mempunyai tingkat kepuasan lebih tinggi. Kepuasan yang diperoleh bukan karena kualitas produk tetapi nilai social atau self-esteem yang membuat pelanggan menjadi puas terhadap merek tertentu. Keempat, harga. Produk yang mempunyai kualitas yang sama tetapi menetapkan harga yang relative murah akan memberikan nilai yang lebih tinggi kepada pelanggannya. Kelima, adalah biaya. Pelanggan yang tidak perlu mengeluarkan biaya tambahan atau tidak perlu membuang waktu untuk mendapatkan suatu produk jasa cenderung puas terhadap produk atau jasa. 


\section{MARKETING MIX PADA JASA PENDIDIKAN TINGGI}

Dalam memasarkan jasa pendidikan tinggi, menurut Kotler \& Fox, dapat menggunakan bauran pemasaran jasa yang terdiri dari 7Ps, yaitu: Program, Price, Place (location and Delivery System, Promotion, Processes, Physical Facilities dan People. Hal ini disebabkan bahwa pendidikan tinggi mempunyai karakteristik tersendiri. Walaupun tergolong pada industri jasa. Adapun karakteristik tersebut, antara lain:

1. Perguruan tinggi termasuk ke dalam kelompok jasa murni (pure services), di mana pemberian jasa yang dilakukan didukung alat kerja atau sarana pendukung semata, seperti ruangan kelas, kursi, meja dan buku-buku.

2. Jasa yang diberikan membutuhkan kehadiran pengguna jasa (mahasiswa), jadi di sini pelanggan yang mendatangi lembaga pendidikan tinggi untuk mendapatkan jasa yang diinginkan.

3. Penerima jasa adalah orang, jadi merupakan pemberi jasa yang berbasis orang sehingga berdasarkan hubungan dengan pengguna jasa (pelanggan/mahasiswa) adalah high contact system yaitu hubungan pemberi jasa dengan pelanggan tinggi. Pelanggan dan penyedia jasa pendidikan terus berinteraksi selama proses pemberian jasa berlangsung. Untuk menerima jasa, pelanggan harus menjadi bagian dari system tersebut

4. Hubungan dengan pelanggan adalah berdasarkan member relationship, di mana pelanggan telah menjadi anggota lembaga pendidikan tinggi, system pembeian jasanya secara terus-menerus dan teratur sesuai dengan kurikulum yang telah ditetapkan.

\section{E. STRATEGI KEUNGGULAN BERSAING}

Porter (dalam Jatmiko, 2003:143-148) menganjurkan 3 (tiga) dasar strageti bersaing yang dapat diadopsi oleh suatu bisnis atau perusahaan, yaitu:

1. Kepemimpinan biaya (the cost leadership) yaitu tindakan integrative yang dirancang untuk memproduksi dan menawarkan barang/jasa pada biaya yang paling rendah relative terhadap para pesaing dengan ciri-ciri yang dapat diterima oleh para pelanggan.

Ulul Albab, Vol. 5 No. 2, 2004 
2. StrategiD ifferensiasiyaitu serangkaian tindakan integrative yang dirancang untuk memproduksi dan menawarkan barang/jasa yang dianggap oleh pelanggan berbeda dalam hal-hal yang penting dan unik bagi mereka. Differensiasi dapat menciptakan keunggulan kompetitif (competitive adventages) melalui loyalitas merek dan ketidakpekaan terhadap perubahan harga dari pelanggan.

3. Strategy Focus. Yaitu serangkaian tindakan integrative yang dirancang untuk memproduksi dan menawarkan barang/jasa yang melayani segmen tertentu untuk produk untuk pasar tertentu, atau pasar geografi tertentu atau yang disebut ceruk pasar.

Kotler (1993;421) memberikan beberapa strategi dalam bersaing, antara lain:

1. Dominan (dominant). Perusahaan/institusi mempu mengendalikan pesaingpesaing yang lain serta memiliki banyak pilihan dalam menentukan strategi.

2. Kuat (strong). Perusahaan/institusi mempu bertindak bebsa tanpa membahayakan posisi jangka panjangnya walaupun pesaing-pesaing berbuat apa saja yang mereka kehendaki.

3. Baik (favorable). Perusahaan/institusi ini memiliki kekuatan yang bisa dimanfaatkan dalam strategi-strategi tertentu serta mempunyai peluang yang lebih di atas rata-rata untuk meningkatkan posisinya

4. Sedang (tenable). Prestasi perusahaan/isntitusi cukup memuaskan untuk menjamin kelangsungan usahanya. Tetapi perusahaan/isntitusi ini sering kalah bersaing karena ulah perusahaan yang dominant serta untuk meningkatkan posisinya ia memiliki peluang yang kurang dari rata-rata industri.

5. Lemah (weak). Perusahaan/institusi ini tampil dengan tidak memuaskan, tetapi masih memiliki peluang untuk perbaikan. Perusahaan/institusi ini harus mengubah diri, kalau tidak maka ia akan terpaksa keluar dari industri.

6. Tidak ada harapan (non-viable) Perusahaan/institusi ini berprestasi dengan sangat tidak memuaskan serta tidak memiliki peluang untuk perbaikan.

Disamping itu, Kotler menyarankan dalma dunia persaingan, juga dapat menggunakan strategi-strategi yang lain, seperti: 
1. Strategi Pemimpin Pasar (Market Leader). Pada strategi ini biasanya perusahaan atau institusi telah memiliki pangsa pasar yang tinggi. Pada posisi ini perusahaan/institusi menjadi titik pusat orientasi para pesaing dan merupakan perusahaan yang ditantang ditiru atau dijauhi. Perusahaan/institusi seperti ini selaluingn tetap nomor satu, sikap ini mendorong untuk mengambil tindakan ke tiga arah. Pertama, perusahaan harus menemukan cara untuk mengembangkan jumlah permintaan keseluruhan. Strategi pengembangan permintaan untuk mencari pelanggan baru dapat dikembangkan melalui, antara lain: (1) strategi penerobosan pasar, (2) strategi pasar baru, (3) strategi perluasan geografis. Kedua, perusahaan harus mampu menjadi tingkat pasar yang dikuasainya dengan cara bartahan maupun menyerang yang baik. Ketiga, perusahaan dapat mencoba meningkatkan pangsa pasarnya meskipun luas pasar tidak berubah.

2. Strategi Penantang Pasar (Market Challenger). Adalah suatu strategi yang digunakan oleh sebuah perusahaan untuk menyerang market leader dan pesaing-pesaingnya. Secara spesisifik strategi yang digunakan antara lain: strategi pemotongan harga, strategi produk yang lebih urah, strategi produk prestise, strategi pengembangbiakan produk, strategi inovasi produk, strategi penyempurnaan jasa pelayanan, strategi inovasi distribusi, strategi penekanan biaya produksi, dan promosi intensif.

3. Strategi Penggarap Relung Pasar (Market Nicher). Kegiatan yang dapat dilakukan, antara lain: (1) spesialisasi pemakai akhir, (2) spesialisasi tingkat vertical; (3) spesialisasi ukuran pelanggan tertentu; (4) melayani pelanggan khusus; (5) melayani daerah geografis tertentu; (6) spesialisasi produk atau lini produk tertentu; (7) spesialisasi produk dengan sifat khusus; (8) spesialisasi kerja pesanan; (9) spesialisasi mutu/harga tertentu; (10) spesialisasi jasa.

\section{METODOLOGI PENELITIAN}

\section{A. LOKASI PENELITIAN}

Penelitian ini mengambil obyek di Univesitas Islam Negeri Malang, Jl. Gajayana No. 50 Malang.

Ulul Albab, Vol. 5 No. 2, 2004 


\section{B. PENDEKATAN PENELITIAN}

Pada penelitian ini, peneliti akan mendeskripsikan berbagai indicator yang dikembangkan berkaitan dengan profil dan segmentasi pengguna jasa pendidikan di UIN Malang. Dengan diketahui deskripsi latar belakang calon mahasiswa, maka digunakan sebagai dasar pengambilan keputusan/kebijakan dalam rangka kegiatan Marketing UIN Malang. Marketing bukan berarti menjual dan membeli, akan tetapi lebih luas, yaitu saling memberikan pemahaman tentang UIN Malang, dapat meningkatkan kinerja pelayanan jasa pendidikan di UIN Malang dan pada gilirannya dapat menciptakan kepuasan atas penggunaan jasa pendidikan.

\section{POPULASI DAN SAMPEL}

Populasi adalah data yang menjadi perhatian peneliti dalam ruang lingkup dan waktu yang ditentukan Margono (2000:118). Populasi dalam penelitian ini adalah calon mahasiswa yang mendaftakan di UIN Malang Tahun Akademik 2004/2005.

Sedangkan sampel adalah bagian atau wakil dari populasi yang diteliti (Arikunto, 1996:188). Sampel dalam penelitian adalah calon mahasiswa (responden) yang mau mengisi kuesioner dan mengembalikan serta di isi dengan baik. Dimana teknik penyebaran kuesioner dengan cara random, artinya setiap calon mahasiswa yang dijadikan responden mendapatkan kuesioner atau hak yang sama untuk mengeluarkan pendapatnya sebagaimana yang ditanyakan oleh kuesioner. Dari jumlah kuesioner yang disebarkan pada waktu pendaftaran mahasiswa baru, kuesioner yang kembali dan layak untuk dilakukan pengujian lebih lanjut berjumlah 542 kuesioner atau responden.

\section{SUMBER DAN TEKNIK PENGUMPULAN DATA}

\section{Sumber Data}

Dalam penelitian ini sumber data bersumber dari data primer. Dimana sumber data primer adalah data yang diperoleh atau digali secara langsung oleh peneliti melalui kuesioner yang dibagikan kepada responden dan informasi yang diberikan oleh informan pada saat melakukan penelitian. 
2. Teknik Pengumpulan Data

Untuk mendapatkan data yang diperlukan dalam penelitian ini, peneliti menggunakan beberapa metode antara lain : (1) Kueioner (angket), adalah sejumlah pertanyaan tertulis yang digunakan untuk memperoleh informasi dari responden (Arikunto, 1996:140). Dalam penelitian ini, responden diminta menjawab pertanyaan mengenai latar belakang calon mahasiswa dan apa yang menjadi motivator untuk menggunakan jasa pendidikan UNN Malang. Jawaban yang diberikan dapat berupa jawaban tertutup dan terbuka. Artinya responden hanya memberikan alternative jawaban yang telah disediakan. Sementara jawaban terbuka, responden mempunyai kebebasan dalam menjawab pertanyaan.

\section{E. ANALISIS DATA}

Terkait dengan sifat penelitian ini yaitu menggambarkan secara deskriptif, maka data yang telah diolah disajikan dalam bentuk tabel-tabel frekuensi dan menggunakan perhitungan prosentase untuk item-item kuesioner yang kuantitatif.

Menurut Indriantoro (1999:170) ukuran yang digunakan dalam deskriptip berupa : frekuensi, tendensi sentral, dispersi dan koefisien. Selanjutnya akan dianalisis dengan menggunakan pendekatan analisis data kualitatif. Artinya datadata kuantitatf dianalisis secara kualitatif dan dihubungkan dengan berbagai teori yang terkait serta fenomena sosial yang muncul. Data-data yang berkaitan dengan kualitatif akan dipetakan sesuai konsep dan variabel yang telah dipersiapkan oleh peneliti dengan melakukan pereduksian yang selanjutnya dapat diungkapkan intisari dari data yang telah diperoleh.

\section{HASIL ANALISIS DATA DAN PEMBAHASAN}

\section{A. DATA MAHASISWA}

Dengan perubahan kelembagaan dari IAIN, STAIN, UIIS, dan yang terakhir adalah UIN. Ternyata dengan perubahan tersebut mendapatkan antusias yang cukup besar dari masyarakat untuk melanjutkan studi lanjut (pendidikan tinggi) di UN Malang, hal ini dibuktikan oleh tabel dibawah ini : 


\section{Data Calon Mahasiswa UIN Malang}

Tabel 1

PERKEMBANGAN CALON MAHASISWA (PENDAFTAR)

\begin{tabular}{|c|c|c|c|c|}
\hline \multirow{2}{*}{ NO } & \multirow{2}{*}{ TAHUN } & \multicolumn{2}{|c|}{ JUMLAH PENDAFTAR } & \multirow{2}{*}{ TOTAL } \\
\cline { 3 - 5 } & & LAKI-LAKI & PEREMPUAN & \\
\hline 1 & 2000 & 561 & 793 & 1354 \\
\hline 2 & 2001 & 678 & 713 & 1391 \\
\hline 3 & 2002 & 782 & 859 & 1641 \\
\hline 4 & 2003 & 793 & 814 & 1607 \\
\hline 5 & 2004 & 874 & 897 & 1771 \\
\hline
\end{tabular}

Sumber : Data \& Informasi UIN Malang (2004)

\section{Data Statistik Mahasiswa}

Tabel 2

DATA STATISTIK MAHASISWA TAHUN 2004

\begin{tabular}{|c|c|c|c|c|}
\hline \multirow{2}{*}{ No } & \multirow{2}{*}{$\begin{array}{l}\text { PROGRAM } \\
\text { STUDI }\end{array}$} & \multicolumn{2}{|c|}{ JUMLAH MAHASISWA } & \multirow{2}{*}{ TOTAL } \\
\hline & & $\begin{array}{l}\text { LAKI- } \\
\text { LAKI }\end{array}$ & $\begin{array}{c}\text { PEREMPU } \\
\text { AN }\end{array}$ & \\
\hline 1 & Penddk.Islam & 579 & 846 & 1.425 \\
\hline 2 & Penddk. IPS & 91 & 126 & 217 \\
\hline 3 & Diploma Il & 25 & 104 & 129 \\
\hline 4 & Syari'ah & 320 & 193 & 513 \\
\hline 5 & Bahasa Arab & 255 & 336 & 591 \\
\hline
\end{tabular}

Ulul Albab, Vol. 5 No. 2, 2004 


\begin{tabular}{|c|c|c|c|c|}
\hline \multirow{2}{*}{ No } & \multirow{2}{*}{$\begin{array}{c}\text { PROGRAM } \\
\text { STUDI }\end{array}$} & \multicolumn{2}{|c|}{ JUMLAH MAHASISWA } & \multirow{2}{*}{ TOTAL } \\
\cline { 3 - 4 } & LAKI-LAKI & $\begin{array}{c}\text { PEREMP } \\
\text { UAN }\end{array}$ & \\
\hline 6 & Bahasa Inggris & 237 & 411 & 648 \\
\hline 7 & Psikologi & 180 & 302 & 482 \\
\hline 8 & Ekonomi & 268 & 319 & 587 \\
\hline 9 & Matematika & 88 & 179 & 267 \\
\hline 10 & Biologi & 64 & 203 & 267 \\
\hline 11 & Kimia & 12 & 32 & 44 \\
\hline 12 & Fisika & 22 & 27 & 49 \\
\hline 13 & Arsitektur & 58 & 27 & 85 \\
\hline 14 & Informatika & 12 & 2 & 14 \\
\hline & T O T A L & 2.211 & 3.107 & 5.318 \\
\hline
\end{tabular}

\section{Sumber : BAK UIN Malang (2004)}

\section{B. DESKRIPSI DAN PEMBAHASAN DATA HASIL PENELITIAN}

Berdasarkan tujuan penelitian, pembahasan hasil penelitian ini akan lebih difokuskan pada beberapa variabel yang digunakan. Hal ini diharapkan akan lebih memfokuskan pembahasan pada pokok permasalahan yang ingin dipecahkan. Pembahasan yang akan digunakana disesuaikan dengan pertanyaan-pertanyaan yang diajukan pada responden, sehingga akan memberikan gambaran yang jelas tentang profil responden yang sesungguhnya.

Ulul Albab, Vol. 5 No. 2, 2004 
Adapun pembahasan setiap materi pertanyaan yang diajukan pada responden adalah sebagi berikut:

\section{Jenis Kelamin Calon Mahasiswa (Responden)}

Dari hasil pengolahan data pada lampiran 2 No 1 , sebagian besar responden yang mengembalikan kuesionernya adalah perempuan sebesar 317 orang dengan prosentase sebesar $58,5 \%$ dari total responden yang mengembalikan sebanyak 542 orang, sedangkan sisanya sebesar 225 orang atau sebesar $41,5 \%$ adalah laki-laki. Hal ini diperjelaskan pada gambar 4 .

\section{Gambar 4}

KOMPOSISI MAHASISWA BERDASARKAN JENIS KELAMIN

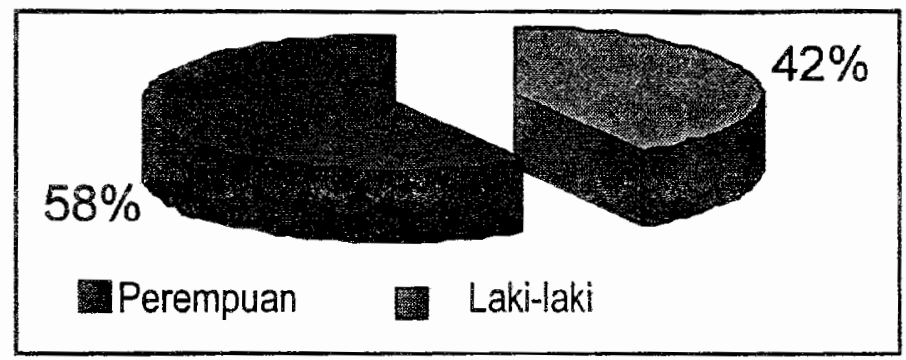

2. Asal Daerah Propinsi Calon Mahasiswa

Pada lampiran 2 Nomor Item 4 dapat di lihat bahwa komposisi calon mahasiswa UIN Malang 79,20\% berasal dari Jawa TImur; Jawa Tengah sebesar $6.5 \%$, selanjutnya wilayah Pulau Sumatra $4,6 \%$; wilayah Propinsi NTB (Nusa Tenggara Barat) sebesar 3.7\%, Pulau Kalimantan sebanyak 2.6\%, Propinsi Jawa Barat termasuk DKI dan Banten, sebanyak sebesar $1.8 \%$, Wilayah Propinsi Nusa Tenggara Timur sebesar $0.7 \%$, Pulau Sulawesi dan sekitarnya sebesar $0.6 \%$ dan Wilayah Papua hanya sebesar $0.4 \%$, sedangkan calon mahasiswa dari luar negeri nampaknya tidak mengembalikan kuesioner karena melalui jalur khusus. Komposisi di atas diperjelas pada dibawah ini.

\section{Berdasarkan Asal Sekolah Calon Mahasiswa}

Dari hasil pengolahan data Nomor Item 5 tentang asal sekolah calon mahasiswa (lihat lampiran 2), sangat jelas bahwa sebagian besar calon mahasiswa UIN Malang berasal dari MA ( Madrasah Aliyah) baik berstatus negeri maupun 
swasta yang tidak berbeda secara signifikan. Di mana MA berstatus negeri $37,50 \%$ dan MA berstatus swasta $33,40 \%$. Selanjutnya SMU Negeri sebesar $13.7 \%$, SMU Swasta $10.3 \%$. Selebihnya jenis lembaga pendidikan lain tidak lebih dari $4 \%$. Untuk memperjelas dapat dilihat pada gambar berikut ini.

\section{Gambar 6}

\section{KOMPOSISI CALON MAHASISWA BERDASARKAN ASAL} SEKOLAH

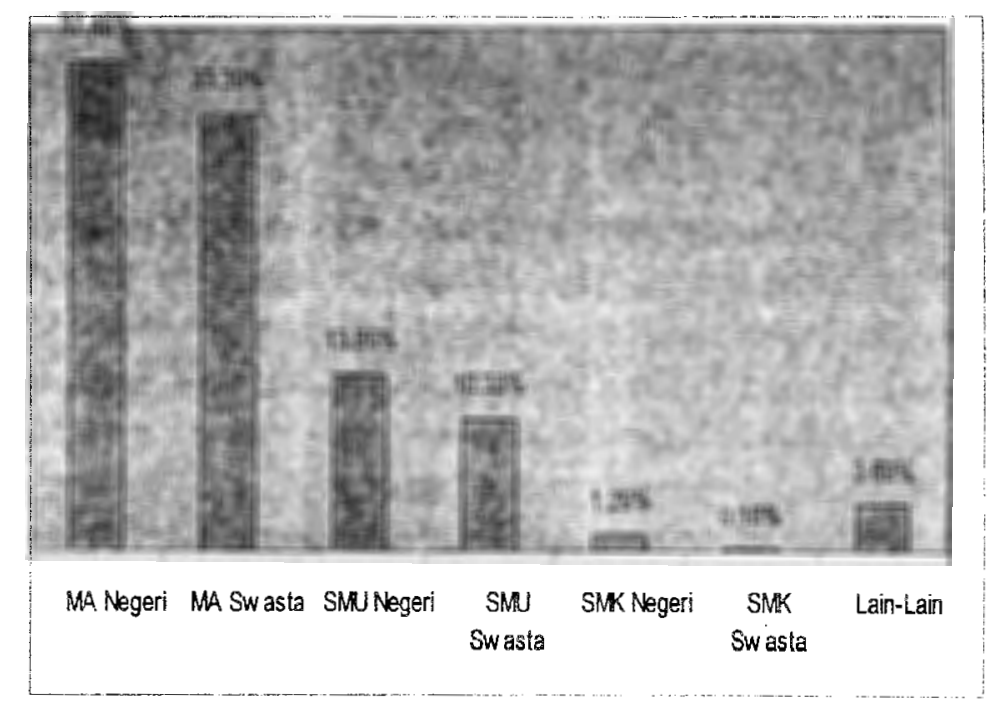

\section{Berdasarkan Pengalaman/Alumni Pondok Pesantren}

Pengolahan data hasil penelitian untuk item kuesioner nomor 6 (lihat lampiran 2), ternyata lebih $50 \%$ calon pengguna jawa pendidikan di UIN Malang adalah murid-murid yang mempunyai pengalaman atau alumni pondok pesantren, yaitu sebesar $65.13 \%$. Sisanya $34,87 \%$ bukan alumni pondok pesantren. Untuk lebih jelasnya dapat dilihat pada gambar dibawah ini. 
Gambar 7

\section{CALON MAHASISWA BERDASARKAN PENGALAMAN/ ALUMNIPONDOK PESANTREN}

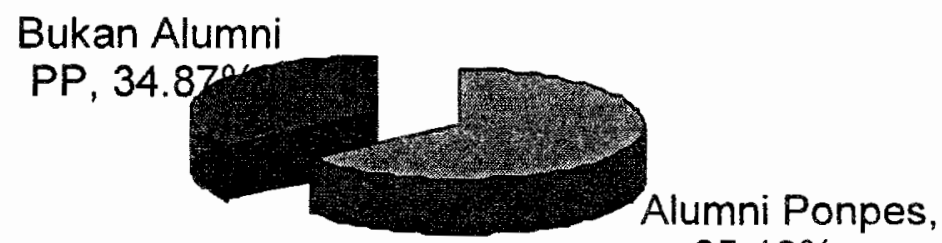

$65.13 \%$

Melihat kondisi di atas, strategi yang perlu dikembangkan adalah strategi pem im pin pasar (Market Leader), dimana strategi ini biasanya sebuah institusi telah memiliki pangsa pasar yang tinggi. Institusi ini selalu ingin nomor satu, sikap ini mendorong untuk mengambil tindakan ketiga arah, yaitu : pertama, institusi harus menemukan cara untuk mengembangkan jumlah permintaan keseluruhan. Fada posisi ini institusi akan selalu mencari pemakai baru, kegunaan baru dan penggunaan yang lebih banyak. Maka sub strategi yang perlu dilakukan adalah strategi penerobosan pasar, strategi pasar baru, dan strategi perluasan geografis. Kedua, institusi harus menjadi tingkat pangsa pasar yang dikuasainya dengan cara bertahan maupun menyerang yang baik. Dan ketiga, institusi dapat mencoba meningkatkan pangsa pasarnya meskipun luas pasar tidak berubah.

\section{Berdasarkan Jumlah Keluarga (anak)}

Dari hasil pengolahan data nomor item kuesioner nomor 9 (lihat lampiran 2) terlihat bahwa sebagian besar calon mahasiswa berasal dari keluarga besar artinya mereke memiliki saudara kandung lebih dari 5 orang dengan komposisi sebesar $42.30 \%$; selanjutnya diikuti oleh jumlah keluarga (anak) sebanyak 4 orang sebesar 23.80\%; jumlah keluarga (anak) 3 sebanyak sebesar $19,00 \%$; dengan 2 anak adalah sebanyak $12.20 \%$ dan anak tunggal sebesar $2.8 \%$. Untuk lebih jelasnya lihat gambar bawah ini: 
Gambar 8

JUMLAH TANGGUNGAN KELUARGA

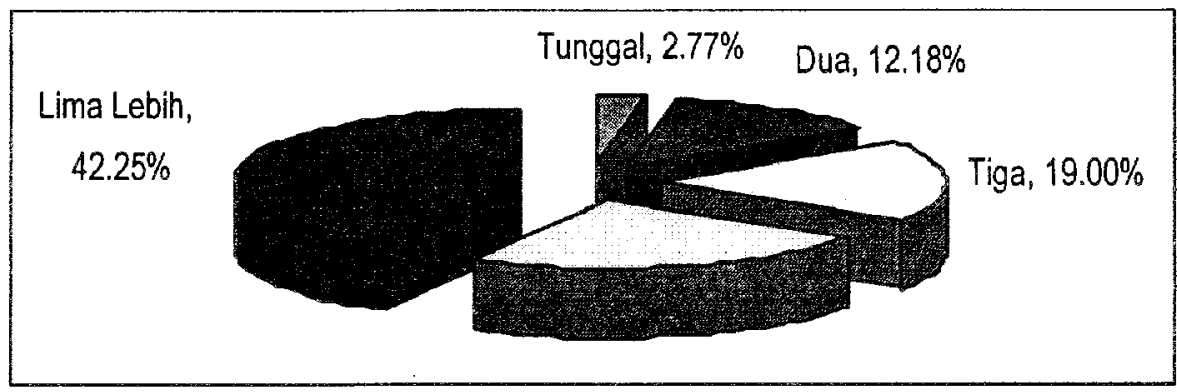

Gambaran di atas memperlihatkan bahwa kondisi keluarga repsonden (calon mahasiswa) adalah dari keluarga yang memiliki tanggunagn ekonomi yang cukup besar.

\section{Berdasarkan Penghasilan Orang Tua}

Pengolahan data hasil penelitian nomor item kuesioner 10 (lihat lampiran 2) terlihat bahwa sebagian besar calon mahasiswa berasal keluarga berpendapatan menengah atau antara Rp 600.000,- sd Rp 1.000.000,-sebebsar 25,10\%; pendapatan Rp 300.000,- sd Rp 600.000,- sebanyak 22,10\%; pendapatan Rp 1.000.000,- sd Rp 1.500.000,- sebanyak 15.90\%; pendapatan di atas Rp 1.500 .000 - sebesar $11.4 \%$, dan terakhir pendapatan kurang dari Rp 100.000,sebanyak $5,20 \%$.

Gambar 9.

DATA PENDAPATAN ORANG TUA CALON MAHASISWA

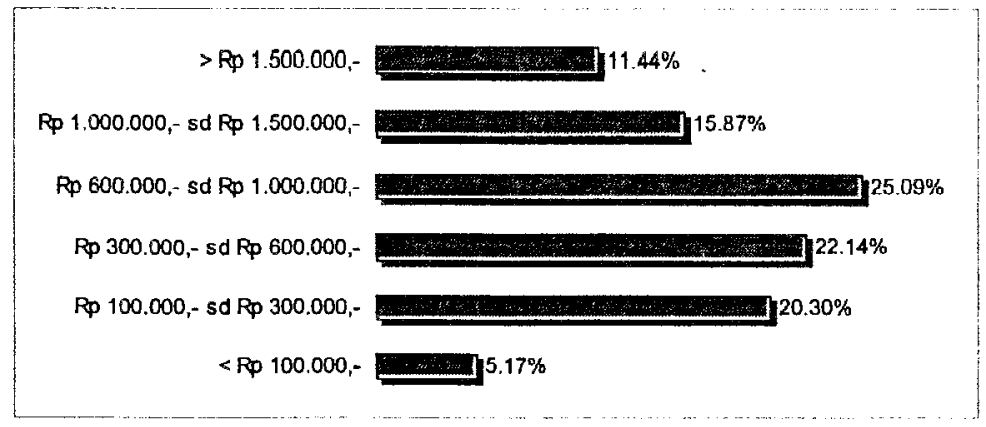

Ulul Albab, Vol. 5 No. 2, 2004 


\section{Sumber Informasi Calon Mahasiswa tentang UIN Malang}

Item kuesioner nomor 11 adalah untuk menggali dari mana calon mahasiswa (masyarakat) mengetahui tentang UIN Malang. Setelah dilakukan pengolahan data sebagian besar memperoleh informasi dari brosur, secara statistic ditunjukan sebesar $29,50 \%$; teman sebanyak $26,60 \%$; dari orang tua atau keluargan sebesar $22,00 \%$; dari guru sebesar $16,10 \%$; lain-lain sebesar $3,10 \%$, dan melalui media massa sebesar $2,80 \%$. Secara grafik dapat dilihat dibawah ini.

Gambar 10

SUMBER INFORMASI CALON MAHASISWA UIN MALANG

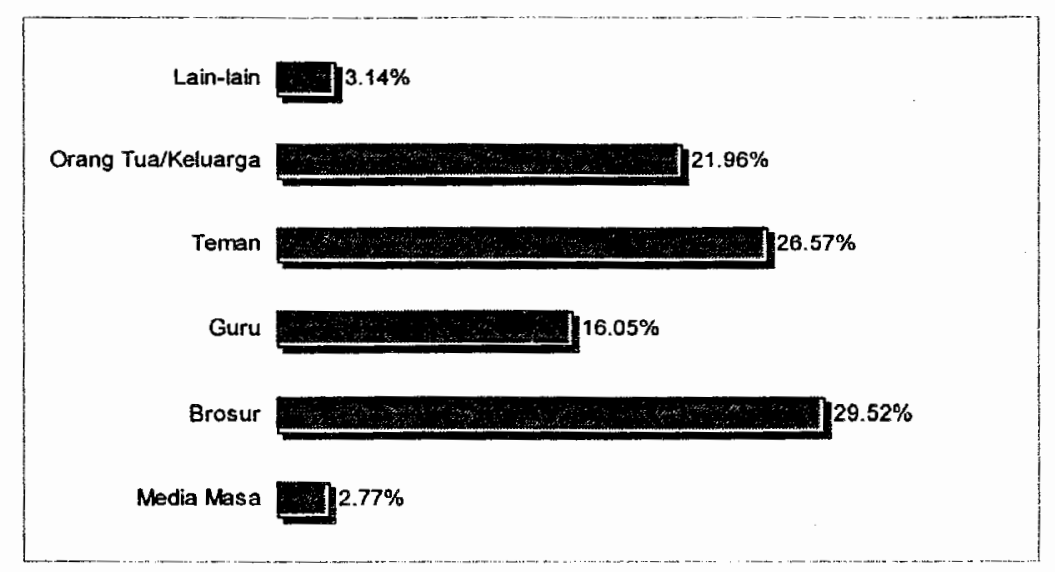

Strategi kedepan yang perlu dipertimbangkan adalah penggunaan media teknologi informasi, karena masyarakat sekarang sudah banyak yang menggunakan internet, terutama yang ada di wilayah jauh, khusus calon mahasiswa luar negeri.

\section{Pengetahuan Calon Mahasiswa tentang Fakultas/Program Studi UIN Malang}

Berdasarkan hasil pengolahan data tentang pengetahuan calon mahasiswa terhadap fakultas/program studi di UIN Malang mempunyai perbandingan prosentase hampir 50\%:50\%. Artinya yang sudah mengetahui fakultas/program 
studi di UIN Malang sebanyak 55,9\%; sedangkan yang belum atau tidak mengetahui 44,1\%. Untuk lebih jelasnya dapat dicermati melalui gambar 11 .

Oleh sebab itu, strateginya adalah menyampaikan program-program yang ada di UIN Malang secara langsung kepada sasaran calon mahasiswa potensial yaitu murid-murid madrasah aliyah baik negeri maupun swasta terutama yang berada di komplek pondok pesantren, dengan menggunakan forum-forum seminbar, penjelasan langsung, atau bentuk yang lain.

Gambar 11

\section{PENGETAHUAN CALON MAHASISWA TENTANG FAKULTAS DAN PROGRAM STUDI DI UIN MALANG}

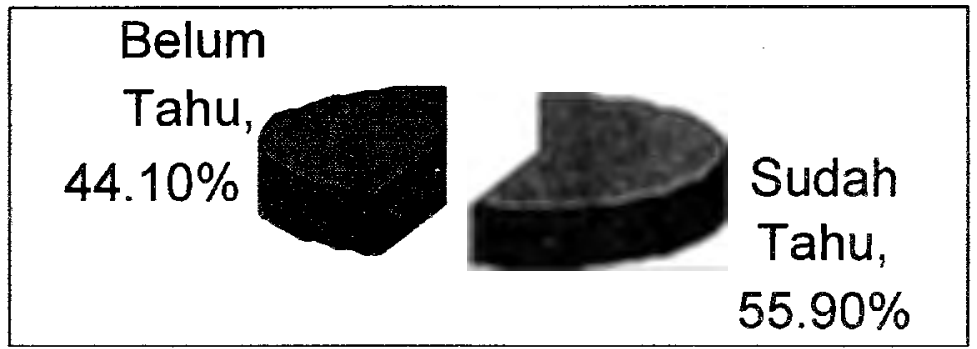

\section{Sumber Motivasi Calon Mahasiswa Studi di UIN Malang}

Item kuesioner yang satu ini adalah untuk mendeskripsikan sumber-sumber responden (calon mahasiswa) untuk melakukan studi di UIN Malang. Hal ini penting untuk digali karena menyangkut proses belajar mengajar (PBM). Ketika sumber motivasi berasal dari internal individu (person), maka dapat diramalkan kegiatan proses belajar mengajar mahasiswa juga akan lebih baik, dibandingkan dengan mahasiswa yang sumber motivasinya berasal dari eksternal - orang tua, saudara, ikut-ikut teman atau yang lain.

Ternyata dari pengolahan data hasil penelitian pada item ini, $71,20 \%$ sumber motivasi belajar di UIN Malang karena diri mahasiswa sendiri, $21,80 \%$ calon mahasiswa melanjutkan studi di UIN Malang didorong oleh orang tua, selebihnya tidak kurang dari $7 \%$ dipengaruhi oleh beberapa factor antara lain saudara, guru, ikut teman, dan lain-lain. Sebagaimana gambar berikut ini. 
Gambar 12

\section{SUMBER MOTIVASI CALON MAHASISWA STUDI \\ DI UIN MALANG}

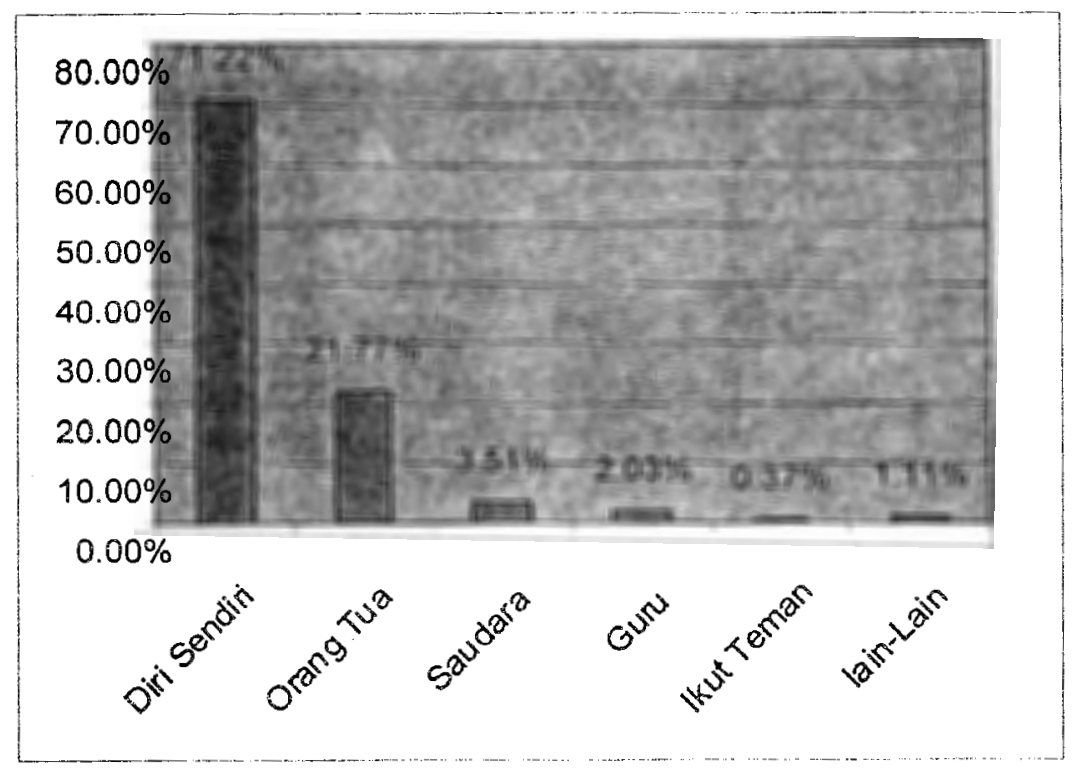

\section{Anggota Keluarga Alumni/Studi di UIN Malang}

Selama ini persoalan alumni belum tergarap sama sekali oleh IAIN/STAIN yang sekarang UIN Malang. Padahal alumni jika dikaji lebih jauh mempunyai kekuatan yang potensial dalam memasarkan atau menyebarkan informasi tentang UIN Malang ke depan. Karena para alumni mempunyai rasa emosional yang cukup tinggi terhadap almamaternya. Hal ini sesuai dengan teori pelayanan jasa pendidikan yang bersifat High-Contact Services. Hasil pengolahan data sebagaimana lampiran 2 , calon mahasiswa atau mungkin mahasiswa yang sedang menempung pendidikan di UIN lebih dari $50 \%$ mempunyai orang tua atau saudara yang pernah belajar di lembaga pendidikan yang sekarang UIN Malang ini. Hal ini dibuktikan sebesar $65,5 \%$ responden mengatakan memiliki keluarga alumni IAIN/STAIN di kala itu. Dan sebesar $34,5 \%$ menyatakan tidak mempunyai 
keluarga alumni IAIN/STAIN. Hal ini menunjukkan bahwa, peranan alumni mempunyai peranan yang cukup besar di dalam membantu penyebaran informasi tentang UIN Malang, lebih lanjut perlu ada wadah alumni dan database alumni dalam rangka untuk melacak keberadaan alumni. Sehingga strategi marketing perlu adaanya jaringan yang kuat dalam mempererat tali silaturrahmi antar alumni, salah satunya adengan pembentukan Ikatan Keluarga Alumni UIN Malang. Lebih tegasnya dapat dicermati pada gambar di bawah ini.

Gambar 13

KELUARGA ANGGOTA ALUMNI UNN MALANG

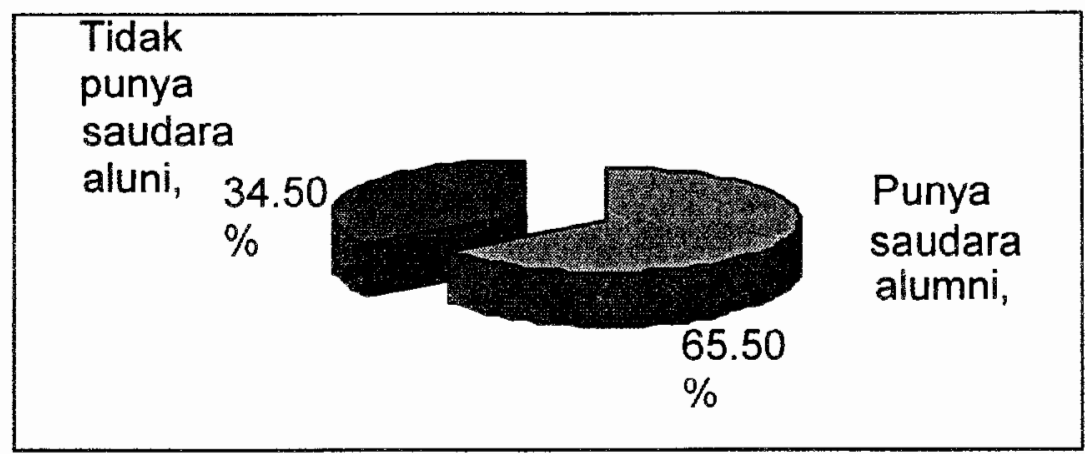

\section{Mendaftar Perguruan Tinggi selain UIN Malang}

Tujuan dari item kuesioner ini adalah untuk mendeskripsikan sebarapa jauh posisi UIN Malang dari sudut pandang calon mahasiswa dibandingkan dengan perguruan tinggi agama atau perguruan tinggi umum lainnya. Ternyata hasilnya cukup mengejutkan sebesar $78,00 \%$ menyatakan tidak mendaftarkan diri di perguruan tinggi lain, sedangkan $22,00 \%$ dari responden menyatakan juga mendaftarkan ke perguruan tinggi lain. Jika hal ini benar bahwa pengisian kuesioner ini sesuai dengan hati nurani responden, maka posisi UNN Malang di mata masyarakat khususnya yang menjadi segmentasi akan lebih baik, maka perlu ada strategi bertahan atau menyerang (Market Challengger). Secara tegas data di atas dapat juga dilihat pada grafik berikut ini.

Ulul Albab, Vol. 5 No. 2, 2004 
Gambar 14

CALON MAHASISWA MENDAFTAR DI PERGURUAN TINGGI LAIN

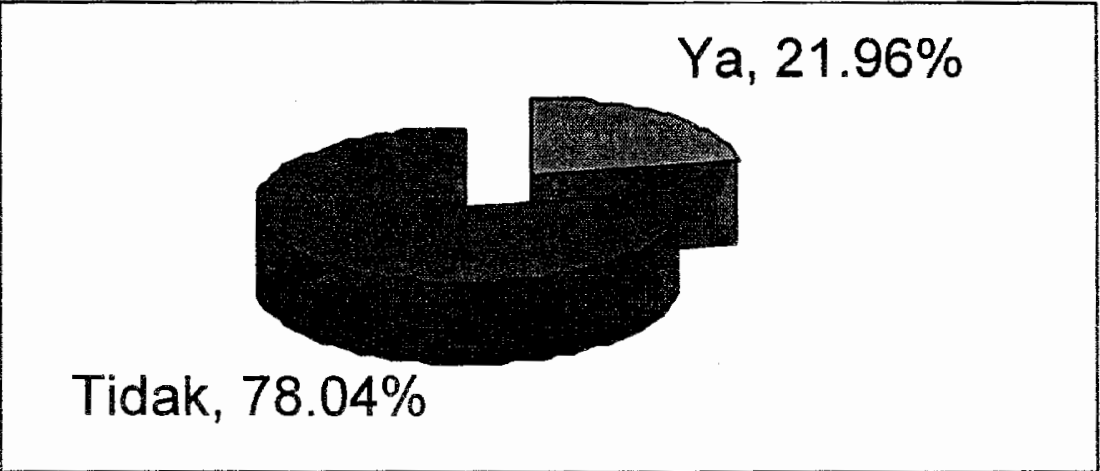

\section{Pilihan Prioritas Calon Mahasiswa terhadap UIN Malang}

Dari hasil nomor 11 di atas, sebesar $22,00 \%$ yang menyatakan mendaftarkan diri lebih dari satu perguruan tinggi, dan seandainya sama-sama diterima antara UN Malang dengan perguruan tinggi lain, sebesar $93,90 \%$ mengatakan komitmennya untuk masuk/studi di UNN Malang, dan 6,10\% menyatakan akan masuk perguruan tinggi selain UIN Malang. Akan tetapi persoalan ini nampaknya perlu ada penelitian lebih jauh kepada mahasiswa yang saat sedang melakukan studi atau aktif studi.

Gambar 15

\section{PILIHAN PRIORITAS CALON MAHASISWA TERHADAP UIN MALANG}

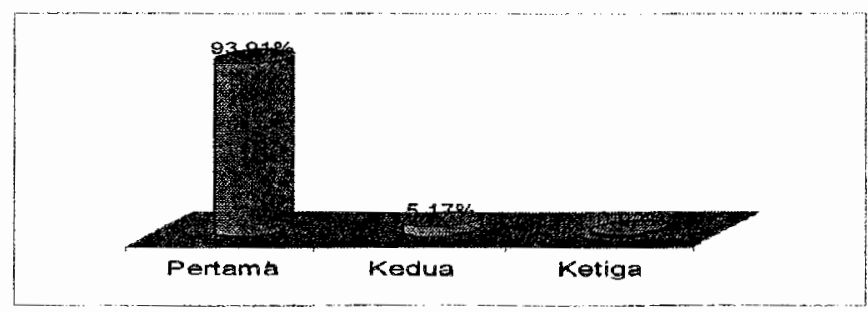

Ulul Albab, Vol. 5 No. 2, 2004 


\section{Pengetahuan Calon Mahsiswa tentang Kurikulum Program Studi yang ditawarkan}

Dari hasil penelitian, ternyata sebesar lebih dari 50\% menyatakan belum tahu tentang kurikulum program studi yang akan dipilih. Lebih jelasnya dapat dilihat pada gambar berikut ini.

Gambar 16

\section{PENGETAHUAN CALON MAHASISWA TENTANG KURIKULUM PROGRAM STUDI YANG DITAWARKAN}

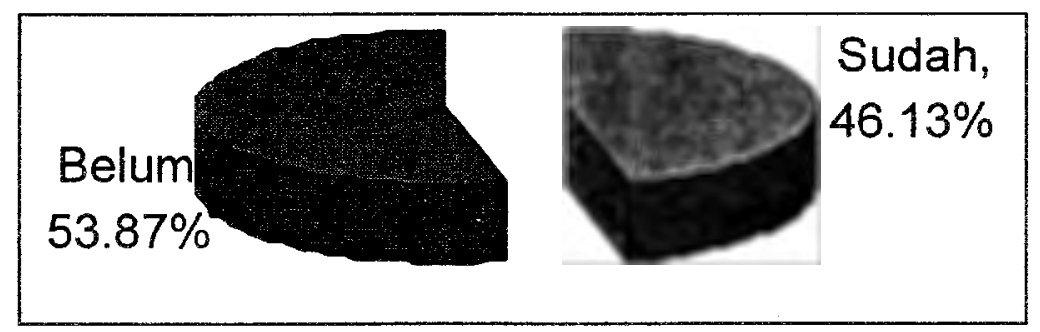

UIN Malang dalam strategi Marketingnya harus menampilkan profil-profil setiap program studi dan menyertakan daftar kurikulum. Sehingga calon mahasiswa dapat memahami kurikulum yang akan diikuti. Atau akan lebih baik, jika UIN Malang dapat menjelaskan profil program studi termasuk kurikulumnya ini dengan system jemput bola, khususnya kepada pasar sasaran (market share) UNN Malang yaitu murid-murid Madrasah Aliyah. Dari kegiatan ini diharapkan dapat menghasilkan dampak positif calon mahasiswa yang berasal dari selain Madrasah Aliyah. Bahwa UNN Malang sudah berubaha paradigmanya dari IAIN/STAIN, yang notabene hanya program studi agama yang ada, tetapi sekarang sudah ada program studi umum murni di tambah dengan program ma'had dan PKPBA sebagai differensiasinya dengan perguruan tinggi lain di Indonesia.

Ulul Albab, Vol. 5 No. 2, 2004 


\section{KESIMPULAN DAN SARAN}

\section{A. Kesimpulan}

Berangkat dari rumusan dan tujuan serta hasil penelitian, maka dapat disimpulkan bahwa :

1. Segmentasi pengguna jasa pendidikan di UIN Malang, dapat dilihat melalui beberapa variabel, antara lain :

a. Variabel Geografis. Secara geografis segmentasi UIN Malang adalah masyarakat Jawa Timur sebesar $79,20 \%$. Bila dilihat kota kelahiran nampaknya relative merata daerah-daerah yang ada di Jawa Timur, sedangkan lokasi sekolah sebagian berasal dari kota Jombang dan Malang.

b. Variabel Demografis. Tingkat latar belakang pendidikan penggguna jasa pendidikan UIN Malang adalah alumni-alumni Madrasah Aliyah. Jika ditotal lebih $70 \%$ mahasiswa UIN Malang adalah alumni madrasah aliyah baik swasta maupun negeri. Pengalaman belajar di pondok pesantren sebesar $65,10 \%$ selebihnya tidak belajar di pondok pesantren. Sementara pekerjaan orang tua sebagian besar adalah petani dan guru, ukuran keluarga cukup besar $42,30 \%$ lebih dari lima saudara dan $23,80 \%$ berjumlah empat bersaudara, tiga saudara $19,00 \%$, dan $12,20 \%$ dua saudara, serta $2,80 \%$ anak tunggal. Apabila dilihat dari jenis kelamin $58,50 \%$ adalah perempuan sisanya lak-laki. Sosial ekonomi relative menengah ke bawah, hal ini tunjukkan oleh data sebesar $25,10 \%$ berpenghasilan antara $\mathrm{Rp} 600.000$,sd Rp 1.000.000,-; pendapatan Rp 100.000,- sd Rp 300.000,- sebesar $20,30 \%$; sebesar $22,10 \%$ menyatakan pendapatan orang tua $\mathrm{Rp} 300.000$,sd Rp 600.000,-. Jika dikalkulasi dengan jumlah keluarga, maka dapat dijustifikasi bahwa secara social ekonomi pengguna jasa pendidikan UIN Malang adalah menengah ke bawah.

2. Berkaitan minat mahasiswa studi di UIN Malang, sangat beraneka ragam, sesuai program studi yang dipilih. Akan tetapi jika dihitung secara statistic minat mahasiswa studi di UIN Malang adalah ingin menjadi seorang guru lebih dari 50\% dan ahli dibidang bahasa (penerjemah) sekitar $25 \%$, selebihnya psikologi, komputer, dan banker bank Islam. Sehingga dapat disimpulkan bahwa program studi umumnya nampaknya belum menjadi minat utama mahasiswa 
studi di UIN Malang. Dan alas an utama, calon mahasiswa/masyarakat melanjutkan studi di UIN Malang adalah adanya program Ma'had dan PKPBA.

3. Keputusan calon mahasiswa menggunakan jasa pendidikan UIN Malang adanya informasi bahwa UIN Malang menggabungkan ilmu-ilmu umum (konvensional) dengan ilmu-ilmu agama, positioning yang dikembangkan adalah menjadikan mahasiswa intelektual, professional, yang ulama, atau ulama yang intelektual dan professional. Untuk menuju kesana adanya dukungan program Ma'had Sunan Ampel al Aly dan Program Khusus Perkuliahan Bahasa Arab (PKPBA).

4. Strategi yang perlu dikembangkan dalam rangka pengembangan UIN Malang ke depan adalah strategi pemimpin pasar (Market Leader), dengan alasan UIN Malang telah mempunyai reputasi yang tinggi di mata masyarakat, sehingga program-program ke depan selalu mencari yang berbeda (different) dari program-program yang ada diperguruan tinggi lain, dengan continous improvement. Dan yang kedua adalah strategi penantang pasar (Market Challenger), artinya UIN Malang dalam manejemen harus melihat perkembangan industri jasa, di mana pelayanan menjadi nomor satu dan melihat siapa sebenarnya yang menjadi pesaing utama UIN Malang, sehingga akan tetap menjadi pemimpin pasar dalam dunia pendidikan.

\section{B. Saran}

Untuk meningkatkan kinerja UIN Malang dilihat dari program yang efektif dan efisien, maka beberapa saran yang berkaitan dengan strategi promosi dan segmentasi.

1. Hendaknya kegiatan promosi terlebih dahulu melihat daerah mana, siapa, latar belakang apa calon pengguna jasa pendidikan UIN Malang. Ketika persoalan ini dicermati terlebih dahulu akan menemukan target pasar yang lebih baik, karena hal ini menyangkut persoalan biaya promosi yang cukup besar.

2. Sebaiknya UIN Malang memperhatikan apa yang menjadi minat utama mahasiswa studi di UIN Malang. 
3. Seyogyanya UIN Malang memperhatikan alumni-alumni, karena peran alumni mempunyai peranan yang besar dalam menyebarkan luaskan tentang UIN Malang di masyarakat. Berdasarkan penelitian yang dilakukan oleh handy Irawan, setiap orang yang merasa puas akan memberikan informasi terbaik 6-7 orang, sebaliknya ketika orang tidak merasa puas, akan memberikan informasi jelek 8-10 orang. Hal ini, bisa jadi akan berlaku di dunia pendidikan, khususnya alumni.

\section{Rekomendasi}

Untuk meningkat kinerja pelayanan UIN Malang kepada mahasiswa atau masyarakat sebaiknya dibentuk divisi atau bagian marketing UIN Malang, di mana divisi atau bagian ini bekerja sebagai marketernya UIN Malang. 